\title{
STRESS, LAMA TIDUR, LAMA PENGGUNAAN HP DAN HUBUNGANNYA DENGAN DISMENORHOE
}

\author{
${ }^{1}$ Khamidah Achyar, ${ }^{2}$ Isnaeni Rofiqoch \\ ${ }^{1}$ Email: khamidahachyar30@gmail.com \\ ${ }^{1,2}$ Program Studi Kebidanan Fakultas Ilmu Kesehatan, Universitas Muhammadiyah Purwokerto.
}

\begin{abstract}
ABSTRAK
Menurut WHO (2010) terdapat 75\% remaja yang mengalami gangguan menstruasi. Berdasarkan hasil penelitian prevalensi dismenorea, sebesar 30-60\%. Tujuan penelitian yaitu untuk menganalisis hubungan stress belajar, lama tidur dan lama penggunaan HP dengan dismenore. Metode penelitian analitik dengan rancangan potong silang ini dilakukan pada mahasiswa di Kampus Prodi Kebidanan S1 Fakultas Ilmu Kesehatan Universitas Muhammadiyah Purwokerto pada November 2019-Januari 2020 sebanyak 55 orang. Analisis data dengan menggunakan chi-kuadrat.. Hasil penelitian, responden yang mengalami dismenore 32 dari 55 orang $(58,18 \%)$. Terdapat hubungan bermakna antara stress belajar $(p=0,01)$, lama tidur $(p=0,005)$ dan lama menggunakan $\mathrm{Hp}(p=0,000)$ dengan dismenore. Kesimpulan: Stress belajar, lama tidur dan lama penggunaan HP berhubungan dengan dismenorea.
\end{abstract}

Kata kunci: Dismenore, Lama tidur, Lama penggunaan HP, Stres belajar

ABSTRACT
According to WHO (2010) there are 75\% of adolescents who experience menstrual disorders. Based on the results of the study, the prevalence of dysmenorrhoea is 30-60\%. The purpose of this research is to analyze the relationship between learning stress, sleep duration, and duration of cell phone use with dysmenorrhea. The analytic research method with cross-sectional design was conducted on 55 students in the Campus of Midwifery Study Program at the Faculty of Health, Muhammadiyah University, Purwokerto in November 2019-January 2020. Data analysis using chi-square. The results of the study, respondents who experienced dysmenorrhea 32 of 55 people (58.18\%). There was a significant relationship between learning stress $(p=0.01)$, sleep duration $(p=0.005)$ and length of time using Hp $(p$ $=0,000)$ with dysmenorrhea. Conclusion: Stress of learning, sleep duration and length of cell phone use are associated with dysmenorrhoea

Keywords: Dysmenorrhea, Length of sleep, Duration of cell phone use, Stress of learning

\section{PENDAHULUAN}

Wanita dengan reproduksi sehat ditandai dengan menstruasi sehat. Beberapa wanita mengalami permasalahan dalam menstruasi diantaranya dismenore, Premenatruasi sindrom (PMS), siklus yang tidak teratur maupun perdarahan diluar siklus. Menurut WHO (2010) terdapat 75\% remaja yang mengalami gangguan menstruasi. Hasil penelitian menyebutkan bahwa kejadian gangguan menstruasi sebesar $60,20 \%$, dismenore dan PMS masing-masing sebesar 30\% (Novita R, 2018). Hasil penelitian yang lain menyebutkan gangguan menstruasi terjadi pada 73,3\% mahasiswi dengan gangguan yang paling sering terjadi yaitu dysmenorrhea sebanyak 63,3\%. Sebagian besar mahasiswi tersebut memiliki aktivitas fisik harian yang cukup yaitu sebanyak $60 \%$.Namun tidak ditemukan adanya hubungan antara aktivitas fisik harian dan gangguan menstruasi.(Anindita P.,et.al, 2016). Kejadian dismenore primer penelitian lain menyebutkan di kalangan siswa perempuan ditemukan $64,7 \%$.Prevalensi dismenore primer yang tinggi ada kaitannya dengan siklus menstruasi yang tidak teratur dan mempuyai riwayat keluarga dismenore.(Azagew AW,et.al, 2020).

Faktor risiko yang berhubungan dengan kejadian dismenore yaitu PMS. Hasil penelitian bahwa tingkat PMS sedang-berat dan gangguan dysphoric pramenstruasi masing-masing adalah $9,7 \%$ dan $2,2 \%$. Sebanyak 121 siswa $(11,9 \%)$ diklasifikasikan memiliki kelompok PMS(-), PMS (+). Perbedaan signifikan diamati antara kelompok PMS (+) dan PMS (-) dalam usia saat menarche, nyeri haid, gangguan hypnagogic, waktu penggunaan Internet yang lama, makan sarapan, mengunyah dengan baik, dan menjadi anggota klub olahraga .Analisis multivariat mengungkapkan bahwa faktor risiko untuk PMS adalah nyeri haid 4,74 kali lebih besar, gangguan hipnagogik, fraktur stres dan waktu penggunaan Internet, memiliki klub olahraga mengurangi risiko PMS.(Yoshimi K, et.al.,2019). Penelitian lain bahwa faktor risiko gangguan menstruasi yaitu beban kerja yang berat bahwa $41 \%$ perawat mengalami gangguan menstruasi. Kami menemukan penanganan disinfektan adalah 
faktor risiko paling signifikan untuk gangguan menstruasi, beban kerja abnormal dan pekerjaan sebagai perawat, Kebisingan, berdiri lama atau sering mengangkat berat, kerja malam, paparan obat anti-kanker, dan kerja lembur secara moderat dikaitkan dengan terjadinya gangguan menstruasi.(Jiang Z,et.al.,2019)

\section{TINJAUAN PUSTAKA}

Dismenore merupakan nyeri saat menstruasi, sebelum, selama maupun setelah menstruasi, dapat bersifat kolik atau terusmenerus. Dismenore dibagi menjadi dua yaitu dismenore primer terjadi sejak menarsche dan tidak ada kelainan alat reproduksi. Dismenore sekunder terjadi kemudian, hal ini karena terdapat kelainan.Penyebab dismenore primer yaitu psikogen, anemia, penyakit TBC, kelelahan, obstruksi alat reproduksi dan faktor hormone endokrin, adapun penyebab dismenore sekunder yaitu karena infeksi, myom, endometriosis, retrofleksi uteri fixate dan gynatresi. (Ginekologi FK Unpad, 1983).

\section{METODE}

Penelitian analitik dengan rancangan cross sectional, menggunakan kuesioner terhadap 55 mahasiswa Prodi Kebidanan S1 Fakultas Ilmu Kesehatan Universitas Muhammadiyah Purwokerto, pada bulan November 2019-Januari 2020. Kriteria inklusinya yaitu mahasiswa kebidanan dan melaksanakan praktik field lab. Kriteria eksklusi yaitu mahasiswa kebidanan yang tidak melaksanakan field lab dan mengundurkan diri dalam field lab.teknik pengambilan sampling yaitu total sampling. Analisis data menggunakan chi-kuadrat untuk mengetahui peranan hubungan antar variable.

\section{HASIL DAN PEMBAHASAN}

Responden hasil penelitian berjumlah 55 orang. Hasil penelitian seluruh variable dapat dilihat pada tabel 1 distribusi frekuensi.

Tabel 1. Distribusi Frekuensi MasingMasing Variabel

\begin{tabular}{|c|c|c|}
\hline Variabel & Frekuensi & $\begin{array}{l}\text { Persentase } \\
(100 \%)\end{array}$ \\
\hline \multicolumn{3}{|l|}{ Usia } \\
\hline$\leq 19$ tahun & 32 & 58,2 \\
\hline$\geq 20$ tahun & 23 & 41,8 \\
\hline \multicolumn{3}{|l|}{ Kejadian Dismenorhoe } \\
\hline $\mathrm{Ya}$ & 32 & 58,2 \\
\hline Tidak & 23 & 41,8 \\
\hline Total & 55 & 100,0 \\
\hline \multicolumn{3}{|l|}{ Stres Belajar } \\
\hline Ya & 37 & 67,3 \\
\hline Tidak & 18 & 32,7 \\
\hline Total & 55 & 100,0 \\
\hline \multicolumn{3}{|l|}{ Lama Tidur } \\
\hline$\leq 6$ jam & 17 & 30,9 \\
\hline$>6 \mathrm{jam}$ & 38 & 69,1 \\
\hline Total & 55 & 100,0 \\
\hline
\end{tabular}

\begin{tabular}{ccr}
\hline Lama Penggunaan HP & & \\
$\leq 6$ jam & 5 & 9,1 \\
$>6$ jam & 50 & 90,9 \\
Total & 55 & 100,0 \\
\hline
\end{tabular}

Hasil penelitian berdasarkan tabel 1 dapat diuraikan yaitu usia responden mayoritas $\leq 19$ tahun sebanyak 58,2\%, kejadian dismenore $58,2 \%$, responden yang mengalami stress sebanyak 67,3\%, lama tidur > 6 jam sebanyak $69,1 \%$ dan lama penggunaan $\mathrm{Hp}>6$ jam sebanyak 90,9\%. Kejadian dismenore hasil penelitian ini cukup tinggi diatas $50 \%$. Hal ini sesuai dengan beberapa hasil penelitian yang lain, yaitu Anindita P, 63,3\%; Borjigen A. 53,4\%; dan Azagew AW.,64,7\% Angka kejadian dismenore sangat beragam yaitu $30-60 \%$. Usia responden pada penelitian ini 19-20 tahun. sementara pada penelitian yang lain dari mulai usia 15 tahun (Wang Z.Y.,2019), usia 19-22 tahun (Latifah U.,et.al.,2018)

Hasil penelitian yang menunjukkan hubungan antar variable dapat dilihat pada tabel 2. Responden yang stres belajar dan mengalami dismenore sebanyak 41,8\%, Lama tidur $>6$ jam dan mengalami dismenore 47,3\%, serta lama penggunaan $\mathrm{Hp}>6$ jam dan mengalami dismenore $52,7 \%$. Hasil analisis bivariate antara sres belajar dengan dismenore terdapat hubungan dengan nilai $\mathrm{p}=0,01$, antara lama tidur dengan dismenore terdapat hubungan dengan nilai $\mathrm{p}=0,005$ serta lama penggunaan $\mathrm{Hp}$ dengan dismenore terdapat hubungan dengan nilai $\mathrm{p}=0,000$.

Tabel 2. Hubungan antar variable dengan

\begin{tabular}{|c|c|c|c|c|}
\hline \multirow{2}{*}{ Variabel } & \multicolumn{2}{|c|}{ Dismenorhoe } & \multirow[b]{2}{*}{$\begin{array}{c}\text { Total } \\
55(100 \\
\%)\end{array}$} & \multirow[b]{2}{*}{$\rho$} \\
\hline & $\begin{array}{c}\text { Ya } \\
\mathbf{N}=\mathbf{3 2} \\
(\mathbf{5 8 , 2 \%})\end{array}$ & $\begin{array}{c}\text { Tidak } \\
\mathrm{N}=\mathbf{2 3}(\mathbf{4 1 , 8 \% )})\end{array}$ & & \\
\hline \multicolumn{5}{|l|}{ Stres } \\
\hline \multicolumn{5}{|l|}{ Belajar } \\
\hline Ya & $23(41,8 \%)$ & $14(25,4 \%)$ & $\begin{array}{c}37(67, \\
3 \%)\end{array}$ & $\begin{array}{l}0,01 \\
0\end{array}$ \\
\hline Tidak & $9(16,3 \%)$ & $9(16,3 \%)$ & $\begin{array}{c}18(32 \\
7 \%)\end{array}$ & \\
\hline \multicolumn{5}{|l|}{ Lama } \\
\hline \multicolumn{5}{|l|}{ Tidur } \\
\hline$\leq 6 \mathrm{jam}$ & $6(10,9 \%)$ & $11(20 \%)$ & $\begin{array}{c}17(30 \\
9 \%)\end{array}$ & $\begin{array}{l}0,00 \\
5\end{array}$ \\
\hline$>6$ jam & $26(47,3 \%)$ & $12(21,8 \%)$ & $\begin{array}{c}38(69, \\
1 \%)\end{array}$ & \\
\hline \multicolumn{5}{|l|}{$\begin{array}{l}\text { Lama } \\
\text { Pengguna } \\
\text { an HP }\end{array}$} \\
\hline$\leq 6 \mathrm{jam}$ & $3(5,4 \%)$ & $2(3,6 \%)$ & $\begin{array}{c}5(9.1 \\
\%)\end{array}$ & $\begin{array}{c}0, \\
00 \\
0\end{array}$ \\
\hline$>6 \mathrm{jam}$ & $29(52,7 \%)$ & $21(38,2 \%)$ & $\begin{array}{c}50(90.9 \\
\%)\end{array}$ & \\
\hline
\end{tabular}

Hasil penelitian ini yang menunjukkan adanya hubungan antara stress belajar dengan 
dismenore sejalan dengan hasil penelitian Latifah U.,et.al tahun 2018 yaitu tingkat stress sedang sebesar 54\%. Stress belajar yang dialami responden erat kaitannya dengan beban tugas saat praktik dan manajemen waktu. Pengelolaan waktu yang baik dari responden dapat meminimalisir tingkat stress dalam mengerjakan beban tugas. Kecenderungan mahasiswa dalam mengerjakan tugas dalam batas waktu deadline. Pekerjaan yang seharusnya dikerjakan bertahap dilaksanakan dibatas akhir deadline sehingga meningkatkan tingkat stress tersendiri. Tingkat stress yang dirasakan berdampak pada kondisi nyeri saat menstruasi.

Berdasarkan hasil penelitian yang lain, tingkat stress ringan/tinggi dirasakan juga pada penderita nyeri perut akibat infeksi di dalam uterus/endometriosis. Tingkat stress rata-rata 41,78\%.(Brasil DL,et.al.,2019). Berdasarkan hasil peneliti ditempat yang berbeda menunjukkan bahwa lebih dari setengah $(53,4 \%)$ remaja perempuan mengalamai tingkat dismenore yang berbeda. Hal ini karena beberapa faktor yang mempengarihunya. Stres psikologis dipengaruhi oleh usia, tingkat, usia saat menarche, frekuensi perubahan pembalut wanita, pembatasan menstruasi, dismenore, dan pengetahuan, sikap, dan praktik menstruasi. (Borjigen A.,2019). Keparahan dan frekuensi dismenore berkorelasi positif dengan emosi negatif, pengalaman kesepian dan masalah interpersonal, sementara berkorelasi negatif dengan usia saat menarche. (2) Emosi negatif, hubungan romantis dan usia menarche, tetapi bukan masalah kesepian dan interpersonal, secara signifikan berkontribusi pada keparahan dan frekuensi dismenore. (3) Analisis mediasi mengungkapkan bahwa efek kesepian dan masalah interpersonal pada dismenore sepenuhnya dimediasi oleh emosi negatif. (Mou L.2019)

Variable yang kedua tentang lama tidur dan dismenore bahwa hasil penelitian ini menunjukan adanya hubungan. Sebaliknya berdasarkan penelitian lain bahwa nyeri haid secara signifikan dikaitkan dengan peningkatan risiko kantuk di siang hari. (Wang ZY, 2019). Demikian juga sejalan dengan penelitian lainnya bahwa Individu dalam kelompok dismenore memiliki depresi, agresi, insomnia, kantuk siang hari dan skor apnea tidur yang secara signifikan lebih tinggi dibandingkan dengan kontrol normal. (Yang B.,2018). penelitian lain menyebutkan dalam penanganan efektifitas obat antara melatonin dan meloxicam, bahwa efisiensi tidur yang objektif meningkat dan latensi tidur yang objektif menjadi lebih pendek. Kemanjuran melatonin lebih unggul dari meloxicam. Pola hasil saat ini menunjukkan bahwa melatonin dan meloxicam cocok untuk mengobati rasa sakit dan keluhan tidur terkait PD di antara wanita dengan dismenore primer. (Keshavarzi F, at.al.,2018).
Peningkatan yang signifikan secara statistik di sepanjang sebagian besar domain QOL, termasuk nyeri fisik, tidur, konsentrasi, perasaan negatif, hubungan sosial, kapasitas kerja, dan keseluruhan kualitas hidup, diidentifikasi setelah intervensi yoga. Hasil menunjukkan bukti awal untuk yoga sebagai metode peningkatan kualitas hidup yang aman dan efektif untuk wanita dengan dismenore primer (McGovern CE\&Cheung C.,2018.)

Lama menggunakan HP dan dismenore pada penelitian ini terdapat hubungan. Berdasarkan beberapa hasil penelitian belum ditemukan secara langsung adanya hubungan terjadinya dismenore dengan lamanya menggunakan $\mathrm{Hp} /$ mengakses internet. Namun beberapa hasil penelitian menyatakan dampak dari lamanya menggunakan internet erat berhubungan dengan kerusakan otak dan gangguan psikologis. Angka kejadian kecanduan menggunakan internet waniat 14\% (Wang,2019), Sekitar $6 \%$ remaja dikategorikan sebagai pecandu berat.(Sulki Chung,et.al.,2019), disebabkan karena adanya teman sebaya. faktor lingkungan memiliki pengaruh yang lebih besar daripada faktor keluarga atau terkait sekolah.

\section{KESIMPULAN}

Stress belajar, lama tidur dan lama penggunaan HP berhubungan dengan dismenore.

\section{DAFTAR PUSTAKA}

1. Anindita P., Darwin E., Afriwardi.2016. Hubungan Aktivitas Fisik Harian Dengan Gangguan Menstruasi Pada Mahasiswa Fakultas Kedokteran Universitas Andalas. Http://Jurnal.Fk.Unand.ac.id.2016

2. Azagew AW, Kassie DG, Walle TA. 2020. Prevalence Of Primary Dysmenorrhea, Its Intensity, Impact And Associated Factors Among Female Students' At Gondar Town Preparatory School, Northwest Ethiopia. BMC Womens Health. Vol.6;20(1):5

3. Bagian Obstetri \& Ginekologi Fakultas Kedokteran Universitas Padjadjaran Bandung. 1983. Ginekologi. Bandung

4. Bahrami A, Bahrami-Taghanaki H, Khorasanchi Z, Timar A, Jaberi N, Azaryan E, Tayefi M, Ferns GA, Sadeghnia HR, Ghayour-Mobarhan M. 2020. Menstrual Problems In Adolescence: Relationship To Serum Vitamins A And E, And Systemic Inflammation. Arch Gynecol Obstet. Vol;301(1):189-197.

5. Borjigen A, Huang C, Liu M, Lu J, Peng H, Sapkota C, Sheng J.2019. Status and Factors of Menstrual Knowledge, Attitudes, Behaviors and Their Correlation with Psychological Stress in Adolescent Girls. J Pediatr Adolesc Gynecol. Vol. 32(6):584589. 
6. Brasil DL, Montagna E, Trevisan CM, La Rosa VL, Laganà AS, Barbosa $\mathrm{CP}$, Bianco B, Zaia V.2019. Psychological Stress Levels In Women With Endometriosis: Systematic Review And Meta-Analysis of Observational Studies. Minerva Med. Vol. 12.

7. Jiang Z, Wang J, Guo X, Feng L, Yu M, Zhou J, Ye Y, Mei L, Ju L, Yu D, Shi L, Lu Alex C, Yu W, Lou J. 2019. Menstrual Disorders And Occupational Exposures Among Female Nurses: A Nationwide Cross-Sectional Study. Int J Nurs Stud.Vol.;95:49-55.

8. Keshavarzi F, Mahmoudzadeh F, Brand S, Sadeghi Bahmani D, Akbari F, Khazaie H., Ghadami MR.Both. 2018. Melatonin And Meloxicam Improved Sleep And Pain In Females With Primary DysmenorrheaResults From A Double-Blind Cross-Over Intervention Pilot Study. Arch Womens Ment Health. Vol.(6):601-609.

9. Latifah U., Fahmi, Agushybana F., Winarni S. 2018. Faktor-Faktor Yang Hubungan Dengan Gangguan Menstruasi Pada Commuter (Penglaju) Studi Kasus Di Kecamatan Karangawen Kabupaten Demak Tahun 2018. Jurnal Kesehatan Masyarakat (E-Journal). Volume 6, Nomor 5 (Issn: 2356-3346).Http://Ejournal3.Undip.Ac.Id

10. McGovern CE, Cheung C.Yoga and Quality of Life in Women with Primary Dysmenorrhea: A Systematic Review. 2018. J Midwifery Womens Health. Vol;63(4):470-482.

11. Mou L, Lei W, Chen J, Zhang R, Liu K, Liang X. 2019. Mediating Effect Of Interpersonal Relations On Negative Emotions And Dysmenorrhea In Female Adolescents._Gen Psychiatr. Vol.6;32(1):e100008.

12. Mike Z. Yao, PhD, Jing He, PhD, Deborah M. Ko, PhD, and Kaichung Pang, BSSc. 2014. The Influence of Personality, Parental Behaviors, and Self-Esteem on Internet Addiction:A Study of Chinese College Students. Cyber psychology,Behavior,And social networking. Volume 17, Number 2.

13. Novita R.2018. Hubungan Status Gizi dengan Gangguan Menstruasi pada Remaja Putri di SMA Al-Azhar Surabaya. Amerta Nutr. Vol.2 No.2, Hal. 172-181

14. Sulki Chung, Jaekyoung Lee and Hae Kook Lee.2019. Personal Factors, Internet Characteristics, and Environmental
Factors Contributing to AdolescentInternet Addiction: A Public Health Perspective. J. Environ. Res. Public Health Vol.16, 4635.

15. Seung-Yup Lee, Donghwan Lee, Cho Rong Nam, Da Yea Kim, Sera Park, Jun-Gun Kwon,Yong-Sil Kweon, Youngjo Lee, Dai Jin Kim And Jung-Seok Cho.2018. Istinct Patterns Of Internet And SmartphoneRelated Problems Among adolescents By Gender: Latent Class Analysis. Journal Of Behavioral Addictions 7(2), pp. 454-465

16. Vannuccini S, Fondelli F, Clemenza S, Galanti G, Petraglia F.2020. Dysmenorrhea and Heavy Menstrual Bleeding in Elite Female Athletes: Quality of Life and Perceived Stress. Reprod Sci. Vol. 6. P.927

17. Wang ZY, Liu ZZ, Jia CX, Liu X. 2019. Age At Menarche, Menstrual Problems, And Daytime Sleepiness In Chinese Adolescent Girls. Sleep. Vol. 42(6). P.061.

18. Yoshimi K, Shiina M, Takeda T. 2019. Lifestyle Factors Associated With Premenstrual Syndrome: A Cross-Sectional Study Of Japanese High School Students. J Pediatr Adolesc Gynecol. Vol.10. P.01

19. Yilmaz B, Sahin N..2019. The Effects of a Dysmenorrhea Support Program on University Students Who Had Primary Dysmenorrhea: A Randomized Controlled Study. J Pediatr Adolesc Gynecol. Vol.. pII: S1083-3188(19)30377-8.

20. Yang B, Qin QZ, Han LL, Lin J, Chen Y. 2018. Spa Therapy (Balneotherapy) Relieves Mental Stress, Sleep Disorder, And General Health Problems In Sub-Healthy People.

21. Yanhong Wang, Anise M. S. Wuand Joseph T. F. Lau Wanget al. 2016. The Health Belief Model And Number Ofpeers With Internet Addiction As Inter-Related Factors Of Internet Addiction Amongsecondary School Students In Hong Kong. BMC Public Health Vol.16:272 -7 